\title{
IL-33 receptor (ST2) deficiency downregulates myeloid precursors, inflammatory NK and dendritic cells in early phase of sepsis
}

\author{
Zivan M. Babic ${ }^{1}$, Filip Z. Zunic ${ }^{1}$, Jelena M. Pantic², Gordana D. Radosavljevic², Ivan P. Jovanovic²,
} Nebojsa N. Arsenijevic ${ }^{2}$ and Miodrag L. Lukic ${ }^{2^{*}}$

\begin{abstract}
Background: Sepsis is a life-threatening disease mediated by profound disturbances in systemic inflammatory response to infection. IL-33 is multifunctional regulator of numerous aspects of innate and adaptive immune response. The aim of this article was to further evaluate the role of IL-33 receptor (ST2) in different pathways of innate immunity during early polymicrobial sepsis.

Methods: Polymicrobial sepsis was induced using cecal ligation and puncture (CLP) model in ST2 deficient $\left(\mathrm{ST}^{-/-}\right)$and wild type BALB/c mice. Peritoneal and spleen cells were isolated for further phenotyping. Apoptosis was determined by immunohistochemistry and flow cytometry.

Results: Deletion of ST2 leads to increased susceptibility to early manifestations of sepsis as evaluated by clinical signs and survival. These are accompanied by decrease in the total number of neutrophils, eosinophils and mast cells in peritoneal cavity $12 \mathrm{~h}$ after CLP. In early sepsis there was also low number of precursors of myeloid cells in particular

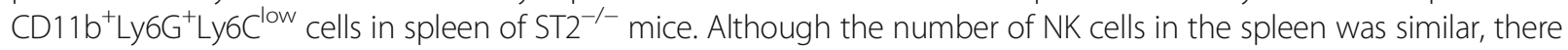
were significant differences in the presence of inflammatory IFN- $\gamma$ and IL-17 producing NK cells. Further, ST2 deletion affects the phenotype and maturation of dendritic cell in sepsis. The total number of dendritic cells in the spleen was lower as well as IL-12 expressing dendritic cells. Finally, there was higher frequency of active caspase-3 positive and early apoptotic cells, in particular CD11c positive cells, in spleen of septic ST2 $2^{-/-}$mice.
\end{abstract}

Conclusion: Taken together, our data provide the evidence that ST2 deficiency in early phase of sepsis downregulates myeloid precursors, inflammatory NK and dendritic cells.

Keywords: ST2, IL-33, Sepsis, Myeloid precursors, NK cells, Dendritic cells

\section{Background}

Sepsis is a life-threatening condition originating from systemic inflammatory response to acute infection followed by tissues and organs injury [1]. In sepsis, the host response triggered by the invasion of microorganism includes pro- and anti-inflammatory response, occurring early and almost simultaneously [2-4]. The

\footnotetext{
* Correspondence: miodrag.lukic@medf.kg.ac.rs

${ }^{2}$ Center for Molecular Medicine and Stem Cell Research, Faculty of Medical Sciences, University of Kragujevac, Svetozara Markovica 69, Kragujevac 34000, Serbia

Full list of author information is available at the end of the article
}

initial hyperinflammatory phase following the recognition of the invading pathogen is rapidly replaced by the long term immunosuppression and subsequent disease aggravation and prolonged sensitivity to superinfections [5]. There is plethora of evidences that numerous immune cells and soluble mediators of inflammation participate in sepsis pathogenesis.

IL-33 is a multifunctional cytokine that participates in various inflammatory responses. It exerts its biological effects via IL-33 receptor containing ST2 molecule and IL-1 receptor accessory protein (IL-1RAcP) expressed on various immune and nonimmune cells (reviewed in

(C) The Author(s). 2018 Open Access This article is distributed under the terms of the Creative Commons Attribution 4.0 International License (http://creativecommons.org/licenses/by/4.0/), which permits unrestricted use, distribution, and 
[6]). Our previously published data revealed that IL-33/ ST2 axis plays an important role in different autoimmune/inflammatory and malignant diseases by exerting multiple effects on both innate and adaptive immunity [7-12]. IL-33 is initially recognized as potent stimulator of adaptive immune response polarization toward $\mathrm{T}$ helper (Th) 2 phenotype following infection or exposure to allergens [13, 14]. However, the expression of IL-33 is strongly upregulated following pro-inflammatory stimuli [15]. As an alarmin released by damaged or necrotic cells IL-33 amplifies innate immune response [16] and induces marked infiltration of neutrophils, macrophages, dendritic cells, and eosinophils in various organs [17].

The elevated level of soluble ST2 in patients with polymicrobial sepsis indicated the important role of IL-33/ ST2 axis in sepsis pathogenesis [18-20]. It was previously reported that IL-33 attenuates sepsis by promoting neutrophil infiltration as well as improving bacterial clearance in the peritoneal cavity [20]. Moreover, ST2 deficient phagocytes have decreased microbicidal capacities during polymicrobial sepsis in mice [20,21]. On the other hand, elevated level of IL-33 is strongly involved in prolonged immunosuppression during the recovery of sepsis which is associated with IL-10 dependent enhancement of regulatory $\mathrm{T}$ cell expansion [22]. Thus, it appears that IL-33/ST2 axis may be responsible for early innate immune response to infection but also for the prolonged immunoincompetence in later phases of sepsis. The aim of the study was to delineate the importance of ST2 molecule in different pathways of innate immunity in the early phase of sepsis. We show that mice lacking ST2 molecule exhibit increased clinical score and mortality rate accompanied with lower number of granulocytes in peritoneal cavity and decreased percentage of splenic immature myeloid cells as early as 12 h following CLP. Natural killer (NK) cells from ST2 ${ }^{-1}$ - mice show lower expression of inflammatory IFN- $\gamma$ and IL-17. Septic ST2 ${ }^{-/-}$mice exhibit decreased presence of splenic inflammatory dendritic cells. The presence of early apoptotic spleen cells, in particular CD $11 \mathrm{c}^{+}$ cells, was increased in septic ST2 ${ }^{-/-}$mice. The obtained data suggest that ST2 receptor signaling is required for the control of early inflammatory response of innate immune cells in sepsis.

\section{Methods}

\section{Animals}

Male, 6 weeks old ST2 deficient $\left(\mathrm{ST}^{-/-}\right)$mice on $\mathrm{BALB} / \mathrm{c}$ background and corresponding wild type (WT) mice were used in the experiments. All mice were housed under standard laboratory conditions $\left(22 \pm 2{ }^{\circ} \mathrm{C}\right.$ with relative humidity of $51 \pm 5 \%$ and a 12 -h light: 12 -h dark cycle) and were administered food and water ad libitum. Twelve hours after the induction of sepsis the mice were sacrificed and peritoneal cells and spleens were isolated for further processing.

\section{CLP procedure}

CLP procedure was performed as described previously [23]. The mice were anesthetized by injecting intraperitoneally the solution of ketamine $(70 \mathrm{mg} / \mathrm{kg}$ ) (Rotexmedica, Trittau, Germany) and xylazine $(13 \mathrm{mg} / \mathrm{kg}$ ) (Interchemie Werken De Adelaar B.V., Venray, Netherlands) and abdominal wall was shaved. After midline laparotomy, the cecum was exposed, ligated below the ileocecal valve without causing intestinal obstruction and then punctured once with a 19G needle. The mice were resuscitated by injecting subcutaneously $1 \mathrm{ml}$ of sterile $0.9 \%$ saline solution and injected subcutaneously tramadol $(20 \mathrm{mg} / \mathrm{kg}$ body weight) (Hemofarm A.D., Vrsac, Serbia) for postoperative analgesia. The animals were returned immediately to a cage with exposure to an infrared heating lamp of $150 \mathrm{~W}$ until they recover from the anesthesia.

\section{Assessment of the severity of sepsis}

The clinical score of sepsis, which included lethargy, piloerection, tremor, periorbital exudate, respiratory distress and diarrhea, was assessed every $6 \mathrm{~h}$ following CLP, as previously described [20]. Each condition was scored as 1 . Mice with the clinical score of $\geq 1$ were considered to show signs of sepsis. The survival rate was monitored for 7 days following CLP.

\section{Isolation of peritoneal leukocytes}

Peritoneal cells were collected using $5 \mathrm{ml}$ of ice-cold PBS (Sigma-Aldrich, St. Louis, MO). After supplementation with $10 \%$ of fetal bovine serum (FBS), the cells were pelleted on $1500 \mathrm{rpm}$ for $8 \mathrm{~min}$ and resuspended in complete cell culture medium (RPMI 1640 supplemented with 10\% FBS) (Invitrogen, Carlsbad, CA, USA) for further analyses.

\section{Isolation of splenocytes}

After the excision of spleens, single-cell suspensions were obtained by mechanical disrupting. Spleens were passed through a $40 \mu \mathrm{m}$ cell strainer (BD Biosciences, San Jose, CA, USA) and resuspended in red blood cell lyses buffer $\left(0.155 \mathrm{M} \mathrm{NH}_{4} \mathrm{Cl}, 0.1 \mathrm{mM}\right.$ EDTA, $10 \mathrm{mM}$ $\mathrm{KHCO}_{3}$ ), vortexed and incubated for $3 \mathrm{~min}$ on $+4{ }^{\circ} \mathrm{C}$. The cells were washed twice on $1500 \mathrm{rpm}$ for $8 \mathrm{~min}$ and resuspended in complete cell culture medium (RPMI 1640 supplemented with 10\% FBS; Invitrogen) for further processing.

\section{Flow cytometry}

Peritoneal cells or splenocytes were resuspended in FACS buffer (PBS with 5 mM EDTA and 0.2\% BSA) and 
incubated with the fluorochrome-conjugated anti-mouse CD11b, Ly6G, Siglec-F, CD117, FceRI, F4/80, Gr-1, Ly6C, CD49b, CD3, CD11c and CD8 $\alpha$ (BD Biosciences/ Miltenyi Biotec $\mathrm{GmbH}$, Bergisch Gladbach, Germany/ Biolegend, San Diego, CA, USA/Invitrogen) antibodies or their respective isotype controls. For intracellular staining, cells were incubated for $5 \mathrm{~h}$ at $37{ }^{\circ} \mathrm{C}$ in the presence of $50 \mathrm{ng} / \mathrm{ml}$ phorbol 12-myristate 13-acetate (PMA) (Sigma-Aldrich), $1 \mu \mathrm{g} / \mathrm{ml}$ ionomycin (Sigma-Aldrich) and Golgi Stop (BD Biosciences). Following the incubation, cells were fixed and permeabilized using BD Cytofix/Cytoperm buffers (BD Biosciences) and labeled with anti-mouse IFN- $\gamma$, IL-17 and IL-12 (BD Biosciences/Biolegend/R\&D Systems, Inc., Minneapolis, MN, USA) (Biolegend, San Diego, CA, USA) antibodies. Isotype controls were included to set gates. Expression of cell surface and intracellular antigens was analyzed with FACSCalibur Flow Cytometer (BD Biosciences). Flow cytometric analysis was conducted with FlowJo (Tree Star) and the numerical values in the dot plots denote percentage of cells within gated quadrants.

\section{Immunohistochemistry}

For immunohistochemical analysis, paraffin-embadded sections of spleen tissue were used. Deparaffinized tissue sections were incubated with primary rabbit anti-mouse active caspase-3 antibody (Novus Biologicals, Littleton, CO, USA, \#NB100-56113) and further visualized using commercial rabbit specific HRP/AEC detection IHC Kit (Abcam, Cambridge, UK). Sections were photomicrographed with a digital camera mounted on light microscope (Olympus BX51, Japan), digitized and analyzed. The caspase 3 positive cells were determined by counting at least 1000 nuclei per slide in five randomly selected fields (at magnification $\times 400$ ). The data were summarized as the mean percentage of positive cells (45 tissues per group). The results are presented as a mean percentage of positive stained cells per field.

\section{Assessment of apoptosis by flow cytometry}

The mononuclear cells isolated from spleen $\left(1 \times 10^{5}\right.$ cells/sample) were resuspended in $1 \times$ Binding buffer (10× Binding buffer contained 0.1 M HEPES, 1.4 M $\mathrm{NaCl}, 25 \mathrm{mM} \mathrm{CaCl}_{2}$ in distilled water, $\mathrm{pH}=7.4$ ) and labeled with FITC-conjugated Annexin V antibody (BD Biosciences) and Propidium iodide (PI) $(50 \mu \mathrm{g} / \mathrm{ml})$ (Sigma-Aldrich) for $15 \mathrm{~min}$ on RT. For the assessment of apoptosis of different immune cells, additional staining with fluorochrome-conjugated anti-mouse CD11c, CD19, F4/80 and CD3 antibodies (BD Biosciences/Miltenyi Biotec $\mathrm{GmbH}$ ) was performed. Further flow cytometric analysis was conducted using FACSCalibur Flow Cytometer (BD Biosciences). The data were analyzed with FlowJo (Tree Star).

\section{Statistical analyses}

All data are presented as means \pm SE. Statistical significance between groups was determined by independent $\mathrm{T}$ test, and where appropriate nonparametric Mann-Whitney U test. For survival rate assessment, statistical testing between samples at each time point was determined using Fisher's exact test. Statistical significance was assumed at ${ }^{*} p<0.05$ and ** $p<0.01$. Statistical analyses were performed using the SPSS 20.0.

\section{Results}

ST2 deficiency accelerates early polymicrobial sepsis and increases mortality

CLP was performed in $\mathrm{ST}_{2}^{-/-}$and WT mice and the signs of sepsis development were monitored every $6 \mathrm{~h}$. The obtained data show that the clinical score in septic ST2 $2^{-/}$ mice is significantly higher compared to WT mice, in particular during first $18 \mathrm{~h}$ following CLP (Fig. 1a). The mortality rate of septic ST2 $2^{-/-}$mice was significantly increased 36-48 $\mathrm{h}$ after CLP procedure (Fig. 1b).

Systemic inflammatory response of septic mice was evaluated by serum levels of various cytokines at $12 \mathrm{~h}$ after CLP. The obtained data showed that CLP induces the production of IL-1 $\beta$, TNF- $\alpha$, IL-12, IFN- $\gamma$, IL-17 as well as IL-10, but there were no differences between two genotypes (data not shown). We also evaluated cellular make-up of peritoneal cavity. Polymicrobial challenge induced marked influx of cells into mouse peritoneal cavity (Fig. 1c). Significantly decreased number of cells was isolated from peritoneal cavity of $\mathrm{ST}^{-1-}$ mice in comparison with WT mice $12 \mathrm{~h}$ following CLP (Fig. 1c). Deletion of ST2 was strongly associated with decreased number of neutrophils

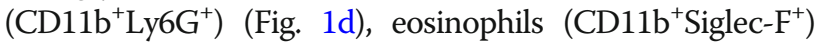
(Fig. 1e) and mast cells $\left(\mathrm{CD} 117^{+} \mathrm{FcERI}^{+}\right.$) (Fig. 1f) in peritoneal cavity in comparison with WT mice after CLP. In addition, polymicrobial challenge markedly increased number of peritoneal macrophages $\left(\mathrm{F} 4 / 80^{+}\right)$, but the difference between two genotypes did not reach statistical significance $12 \mathrm{~h}$ after CLP (Fig. 1g).

\section{The number of myeloid precursor cells is lower in septic $\mathrm{ST}^{-1-}$ mice}

Inflammatory response in sepsis may also depend on myeloid precursor cells which may have pro-inflammatory effects in early and suppressive effects in later phases of sepsis. As shown in Fig. 2a and b, there was lower percent-

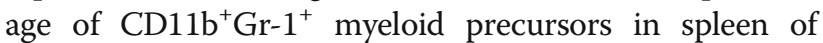
healthy $\mathrm{ST} 2^{-/-}$mice, but in septic mice the difference between two genotypes reached statistical significance in both percentage and total cell number. However, septic mice of both genotypes exhibited marked decrease in percentage and total number of $\mathrm{CD} 11 \mathrm{~b}^{+} \mathrm{Gr}-1^{+}$cells (Fig. 2a). 




Under non-septic condition, there was no difference in both percentage and total number of myeloid precursor cells of granulocytic lineage $\left(\mathrm{CD} 11 \mathrm{~b}^{+} \mathrm{Ly6}\right.$ $\mathrm{G}^{+} \mathrm{Ly}_{6} \mathrm{C}^{\text {low }}$ ) between $\mathrm{ST} 2^{-/-}$and WT mice (Fig. 2c). Further, polymicrobial challenge was accompanied

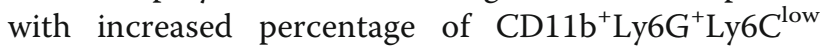
cells in WT, but not in ST2 ${ }^{-/-}$mice (Fig. 2c, left panel). However, the total number of $\mathrm{CD}_{11 \mathrm{~b}^{+} \mathrm{Ly} 6-}$ $\mathrm{G}^{+} \mathrm{Ly} 6 \mathrm{C}^{\text {low }}$ cells was not affected in WT mice after CLP, while septic $\mathrm{ST}_{2}{ }^{-1-}$ mice exhibited lower number of these cells compared to healthy mice (Fig. 2c, right panel). The percentage as well as total number of myeloid precursor cells of granulocytic lineage $\left(\mathrm{CD} 11 \mathrm{~b}^{+} \mathrm{Ly}_{6 \mathrm{G}} \mathrm{Ly}^{+} \mathrm{C}^{\mathrm{low}}\right)$ was significantly lower in septic ST2 $2^{-1-}$ mice in comparison with WT mice (Fig. 2c and e). On the other hand, there was no difference in the percentage of myeloid precursor cells of monocytic lineage $\left(\mathrm{CD} 11 \mathrm{~b}^{+} \mathrm{Ly} 6 \mathrm{G}^{-} \mathrm{Ly} 6 \mathrm{C}^{\text {high }}\right)$ in heathy or septic mice of both genotypes, while the total number of $\mathrm{CD} 11 \mathrm{~b}^{+}$Ly6 $6 \mathrm{G}^{-}$Ly6 $\mathrm{C}^{\text {high }}$ cells was significantly lower in septic compared to healthy mice (Fig. 2d).
Inflammatory (IFN- $\gamma^{+}$and IL-17 $7^{+}$NK cells are decreased in septic ST2 ${ }^{-/-}$mice

Apart from their cytotoxicity, NK cells are important early source of various cytokines engaged in crosstalk with other immune cell types. Although the frequencies of splenic $\mathrm{NK}\left(\mathrm{CD} 49 \mathrm{~b}^{+} \mathrm{CD}^{-}\right)$cells were similar between septic and healthy mice of both genotypes, the total number of NK cells was significantly decreased after CLP (Fig. 3a). Furthermore, the expression of IFN- $\gamma$ and IL-17 was significantly affected in NK cells from septic mice. Significantly decreased percentage and total number of both IFN- $\gamma$ and IL-17 positive NK cells was observed in $\mathrm{ST}_{2}^{-/-}$and WT mice after CLP (Fig. 3b and c). There was no difference in the expression of IFN- $\gamma$ and IL-17 in NK cells between healthy ST2 ${ }^{-/-}$and WT mice, but in septic mice the difference between two genotypes reached statistical significance in both percentage and total cell number. In fact, in spleen of septic $\mathrm{ST} 2^{-1-}$ mice there was significantly decreased expression of IFN- $\gamma$ (Fig. 3b and d) and IL-17 (Fig. 3c and d) among NK cells in comparison with WT mice. 


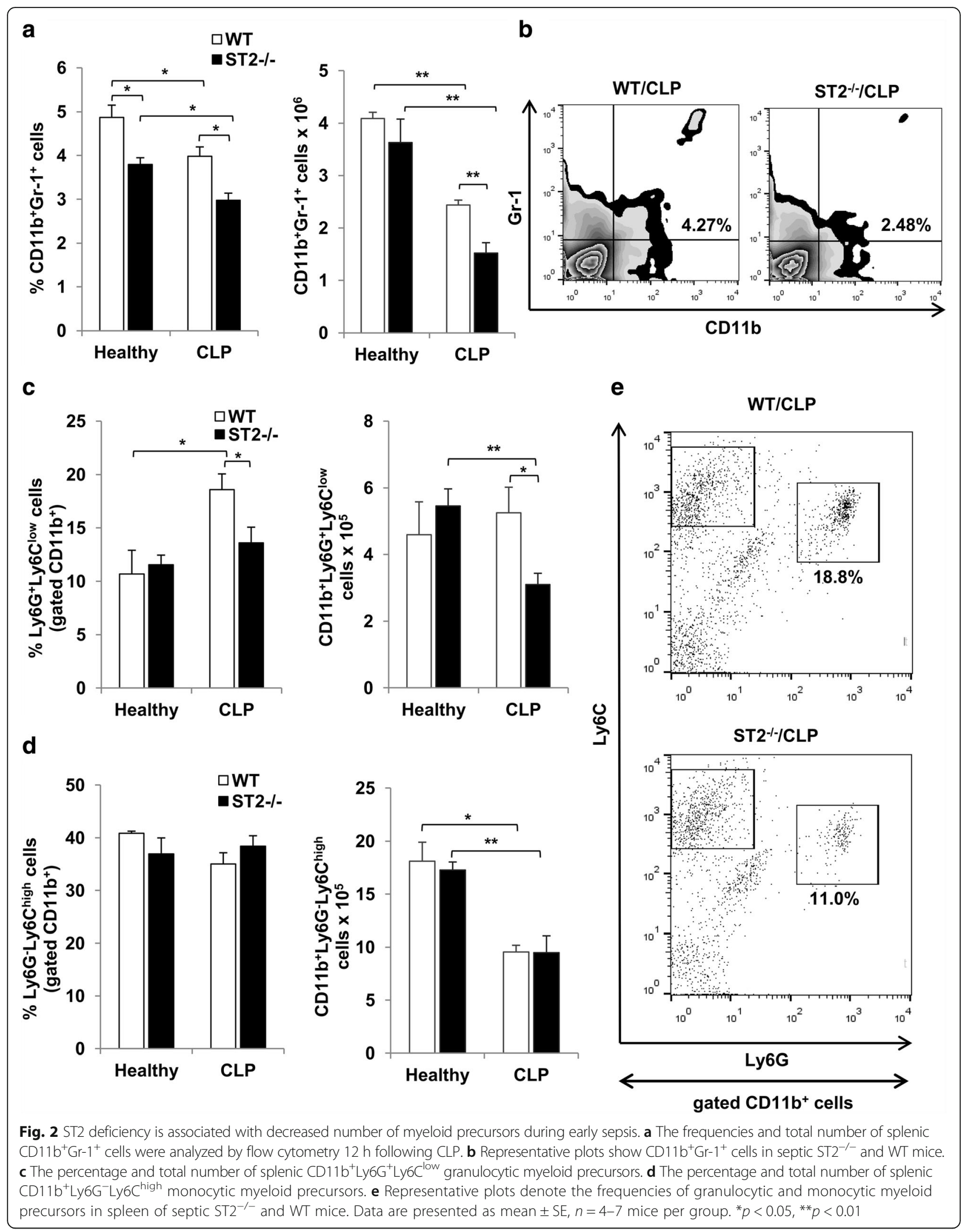




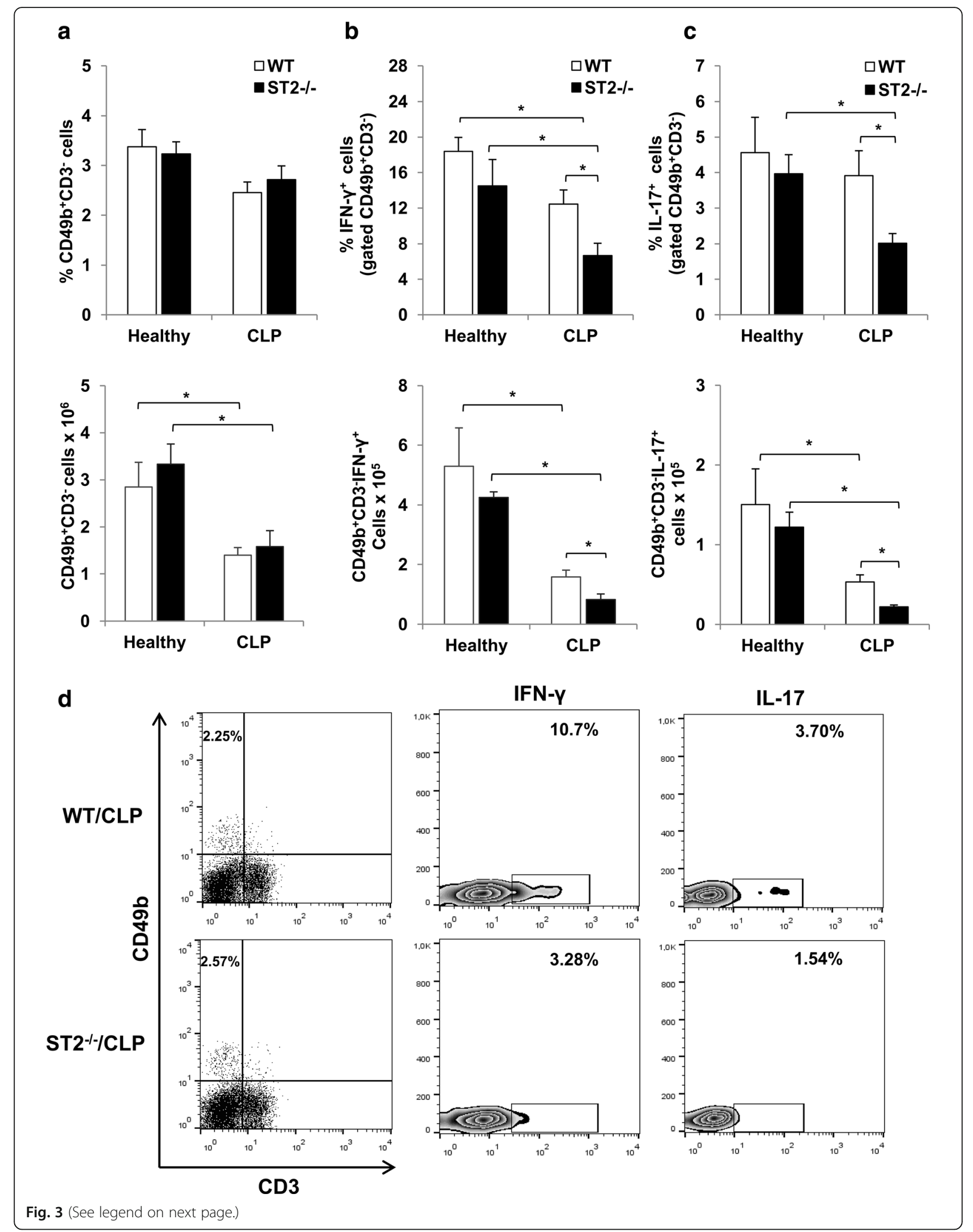


(See figure on previous page.)

Fig. 3 Decreased number of inflammatory NK cells in septic ST2 $2^{-1-}$ mice. a The frequencies and total number of splenic NK (CD49b $\left.\mathrm{b}^{+} \mathrm{CD} 3^{-}\right)$cells were analyzed by flow cytometry $12 \mathrm{~h}$ following CLP. The percentage and total number of splenic IFN- $\gamma(\mathbf{b})$ and IL-17 (c) positive NK (CD49b $\left.{ }^{+} \mathrm{CD} 3^{-}\right)$ cells. $\mathbf{d}$ The representative plots denote decreased expression of IFN- $\gamma$ and IL-17 among the population of NK (CD49b $\left.{ }^{+} \mathrm{CD}^{-}\right)$cells derived from spleen of septic $\mathrm{ST}^{-1-}$ in comparison with WT mice. Data are presented as mean $\pm \mathrm{SE}, n=4-5$ mice per group. ${ }^{*} p<0.05$

\section{Inflammatory dendritic cells are decreased in septic} $\mathrm{ST} 2^{-/-}$mice

In order to further delineate early innate immune response in septic $\mathrm{ST} 2^{-/-}$and WT mice, both presence and functional phenotype of splenic dendritic cells were analyzed $12 \mathrm{~h}$ after CLP. Initially, it was observed that there was no difference in the percentage and total number of dendritic cells $\left(\mathrm{CD} 11 \mathrm{c}^{+}\right)$between healthy ST2 $2^{-/-}$ and WT mice (Fig. 4a). CLP significantly decreased the total number of $\mathrm{CD}_{11 \mathrm{c}^{+}}$cells in WT mice, while in $\mathrm{ST}^{-/-}$mice the difference reached statistical significance in both percentage and total number (Fig. 4a). Twelve hours following CLP the percentage and total number of $\mathrm{CD}_{11 \mathrm{c}^{+}}$cells was significantly lower in septic $\mathrm{ST}^{-/-}$mice in comparison with WT mice (Fig. 4a).
Further, there was no difference in the percentage and total number of CD8 $\alpha$ and IL-12 positive dendritic cells between healthy ST2 ${ }^{-1-}$ and WT mice (Fig. $4 \mathrm{~b}$ and c). However, CLP significantly decreased the total number of $\mathrm{CD}_{8} \alpha^{+}$dendritic cells in WT mice, while in $\mathrm{ST}^{-/-}$ mice the difference reached statistical significance in both percentage and total number (Fig. 4b). In septic condition, $\mathrm{ST}^{-/-}$mice exhibited decreased percentage and total number of $\mathrm{CD} 8 \alpha^{+}$dendritic cells compared to WT mice (Fig. 4b). The polymicrobial challenge was accompanied with increased percentage, but not total number, of IL-12 expressing CD11c ${ }^{+}$cells in WT mice (Fig. 4c). On the other hand, $\mathrm{ST}^{-/-}$mice had significantly lower number of $\mathrm{IL}-12^{+}$dendritic cells after CLP (Fig. 4c, lower panel). In septic condition, $\mathrm{ST}^{-/-}$mice

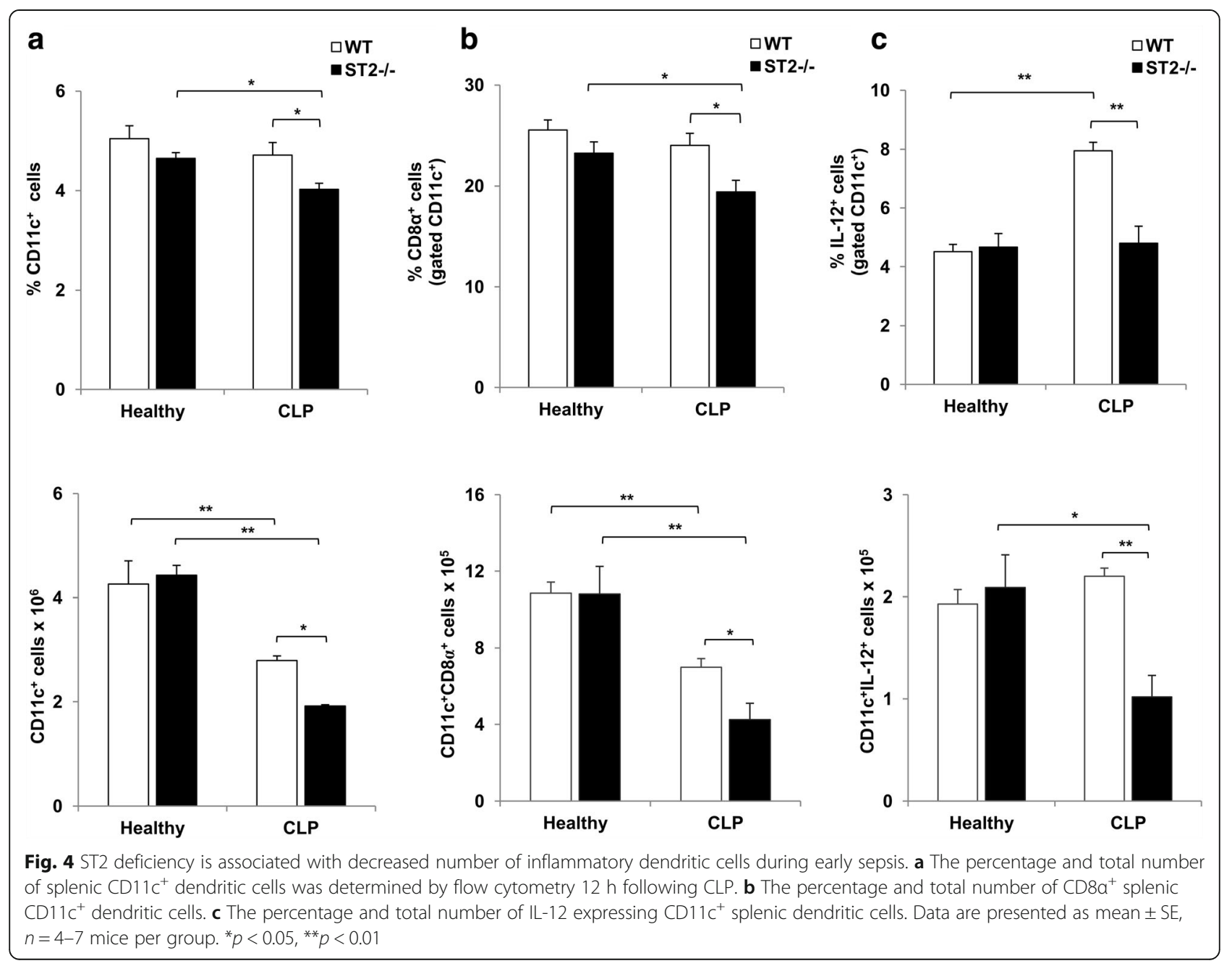


exhibited markedly lower percentage and total number of IL- $12^{+}$dendritic cells compared to WT mice (Fig. 4c).

\section{Sepsis-induced early apoptosis of $\mathrm{CD}_{11 \mathrm{c}^{+} \text {cells is }}$ enhanced in $\mathrm{ST}^{-1-}$ mice}

Immunohistochemistry showed markedly increased number of active caspase-3 positive spleen cells in septic compared to healthy mice $12 \mathrm{~h}$ following CLP (Fig. 5a), thus indicating higher number of cells undergoing apoptosis. Although there was no statistical difference between healthy ST2 ${ }^{-/}$and WT mice, it appears that $\mathrm{ST}_{2}{ }^{-1-}$ mice exhibited significantly increased CLP-induced expression of active caspase- 3 positive spleen cells compared to WT mice (Fig. 5a). In line with immunohistochemistry, sepsis is accompanied with increased percentage of early apoptotic (Annexin $\mathrm{V}^{+} \mathrm{PI}^{-}$) spleen cells independently of mice genotype (Fig. 5b). The frequency of Annexin $\mathrm{V}^{+} \mathrm{PI}^{-}$cells was significantly increased in septic ST2 ${ }^{-/-}$mice in comparison with WT mice (Fig. 5b and c). In order to evaluate which immune cells undergo CLP-induced apoptosis, additional staining for membrane markers of $\mathrm{B}$ and $\mathrm{T}$ cells, dendritic cells and macrophages was performed. First, CLP increased the percentage of Annexin $\mathrm{V}^{+} \mathrm{PI}^{-}$ cells among $\mathrm{CD} 11 \mathrm{c}^{+}$population independently of mice genotype (Fig. 5d), thus indicating early apoptosis of dendritic cells. Further, $\mathrm{ST}^{-/-}$mice exhibited significantly higher frequency of CLP-induced early apoptotic CD11c ${ }^{+}$ cells compared to WT mice (Fig. 5d and e). CLP increased presence of early apoptotic B cells $\left(\mathrm{CD} 19^{+}\right)$in both mice genotypes (Fig. 5f), while the percentage of Annexin $\mathrm{V}^{+} \mathrm{PI}^{-}$macrophages $\left(\mathrm{F} 4 / 80^{+}\right)$(Fig. $\left.5 \mathrm{~g}\right)$ and $\mathrm{T}$ cells $\left(\mathrm{CD}^{+}\right)$ (Fig. 5h) was significantly higher only in $\mathrm{ST}_{2}{ }^{-/}$mice. There was a trend toward increase in early apoptosis of B cells and macrophages in septic ST2 $2^{-/-}$mice in comparison with WT mice, but it did not reach statistical significance $12 \mathrm{~h}$ after CLP (Fig. $5 \mathrm{f}$ and g).

\section{Discussion}

The present study supports the immunoprotective role of ST2 receptor signaling in the early sepsis. ST2 $2^{-/-}$mice exhibited higher clinical score as well as increased mortality rate following CLP in comparison with WT mice. Deletion of ST2 correlates with lower influx of neutrophils, eosinophils and mast cells into peritoneal cavity as well as decreased percentage of splenic myeloid precursor cells $12 \mathrm{~h}$ following CLP. Further, lack of ST2 contributes to decreased presence of splenic inflammatory IFN- $\gamma^{+}$and $\mathrm{IL}-17^{+} \mathrm{NK}$ cells. There was lower presence of total and inflammatory dendritic cells in spleen from $\mathrm{ST} 2^{-/-}$mice. Higher percentage of active caspase- 3 positive and early apoptotic cells, in particular $\mathrm{CD} 11 \mathrm{c}^{+}$cells, was observed in spleen of septic ST2 ${ }^{-/-}$mice.
It has been reported that multiple neutrophil dysfunctions such as impaired bacterial clearance, reduced reactive oxygen species (ROS) production and decreased recruitment to infected tissues due to loss of chemotactic activity underlies the sepsis pathogenesis [24-26]. It appears that mast cells are also participants in acute inflammatory response that release various inflammatory mediators in order to combat the infection during early stage of sepsis [27]. Accordingly, mast cells deficient mice are more susceptible to acute bacterial peritonitis [28]. Although their precise role in sepsis remains unexplored, decreased number of eosinophils correlates with increased mortality in septic patients [29]. Herein, there was marked increase in number of neutrophils, eosinophils, mast cells as well as macrophages in peritoneal cavity of both ST2 ${ }^{-/-}$and WT mice, $12 \mathrm{~h}$ after CLP (Fig. $1 \mathrm{~d}$, e, f and g). However, in line with previous findings [20], ST2 ${ }^{-1-}$ mice exhibited worsen outcome in early sepsis accompanied with lower influx of neutrophils, eosinophils and mast cells (Fig. 1d, e and f). Such findings strongly correspond with the established role of IL-33 in promoting granulocytes influx $[17,30,31]$ and further implicate the important role of IL-33/ST2 axis in initiating innate immune response during sepsis and subsequent efficient bacterial clearance. To these findings we here add the evidence suggesting that ST2 receptor signaling affects myeloid precursors, inflammatory NK and dendritic cells in early phase of sepsis.

Immature myeloid cells are heterogeneous cell population containing progenitors of granulocytes, macrophages


[32]. These cells are initially recognized as potent suppressors of $\mathrm{T}$ cells mediated anti-tumor immune response, thus termed as myeloid-derived suppressor cells (MDSCs) [33]. However, MDSCs seem to be critical participants in most acute inflammatory conditions including systemic inflammatory response during sepsis [32]. It appears that


tremely complex and can either enhance or attenuate inflammatory response depending on the stage of sepsis progression [34, 35]. During early phase of sepsis MDSCs enhance innate immune response and express nitric oxide and proinflammatory cytokines, while in late sepsis MDSCs exhibit arginase activity and express anti-inflammatory cytokines further contributing to the protracted immunoparalysis [36]. The obtained data revealed significantly decreased presence of

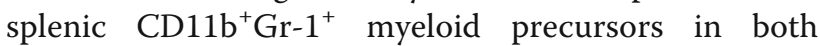
$\mathrm{ST}^{-/-}$and WT mice $12 \mathrm{~h}$ after CLP (Fig. 2a). It was previously reported that exogenous IL-33 enhances accumulation of MDSCs both in murine mammary tumor and spleen [12]. Accordingly, there was decreased percentage of $\mathrm{CD}_{1} 1 \mathrm{~b}^{+} \mathrm{Gr}-1^{+}$myeloid precursors in spleen of $\mathrm{ST}_{2}{ }^{--}$mice in both septic and 





(See figure on previous page.)

Fig. 5 ST2 deficiency enhances early apoptosis of $C D 11 c^{+}$cells in sepsis. a The percentage of active caspase-3 positive spleen cells is assessed by immunohistochemistry. The results are presented as a mean percentage of positive stained nuclei per field ( 5 random fields, $4-5$ tissues per group). Representative images show active caspase-3 positive nuclei in spleen of septic ST2 ${ }^{-/-}$and WT mice (magnification at $\times 400$ ). $\mathbf{b}$ The percentage of early apoptotic Annexin $\mathrm{V}^{+} \mathrm{PI}^{-}$spleen cells is assessed $12 \mathrm{~h}$ after CLP by anti-mouse Annexin $\mathrm{V}$ antibody and PI staining. $\mathbf{c}$ Representative plots denote the percentage of early apoptotic Annexin $\mathrm{V}^{+} \mathrm{PI}^{-}$cells of total spleen cells in septic ST2 ${ }^{-1}$ and WT mice. $\mathbf{d}$ The percentage of early apoptotic Annexin $\mathrm{V}^{+} \mathrm{PI}^{-}$spleen cells among CD11 $\mathrm{c}^{+}$cells. e Representative plots denote the percentage of early apoptotic Annexin $\mathrm{V}^{+} \mathrm{Pl}^{-}$cells of $\mathrm{CD} 11 \mathrm{c}^{+}$spleen cells in septic ST2 $2^{-1-}$ and WT mice. The percentage of early apoptotic Annexin $\mathrm{V}^{+} \mathrm{PI}^{-}$spleen cells among B cells $\left(\mathrm{CD} 19^{+}\right)(\mathbf{f})$, macrophages $\left(\mathrm{F} 4 / 80^{+}\right)(\mathbf{g})$ and $\mathrm{T}$ cells $\left(\mathrm{CD}^{+}\right)(\mathbf{h})$ was shown. Data are presented as mean $\pm \mathrm{SE}, n=4-7$ mice per group. ${ }^{*} p<0.05,{ }^{* *} p<0.01$

healthy conditions, indicating baseline difference between two genotypes (Fig. 2a and b). However, the total number of $\mathrm{CD}_{1} 1 \mathrm{~b}^{+} \mathrm{Gr}-1^{+}$cells did not differ between healthy $\mathrm{ST}^{-1-}$ and WT mice, while septic $\mathrm{ST}^{-1-}$ mice exhibited markedly lower presence of CD $11 b^{+} \mathrm{Gr}-1^{+}$cells (Fig. 2a and b). MDSCs are subsequently divided in two different subpopulations, granulocytic $\mathrm{Ly}_{6 \mathrm{G}}{ }^{+} \mathrm{Ly} 6 \mathrm{C}^{\text {low }}$ and monocytic Ly6G $\mathrm{G}^{-}$Ly6 $\mathrm{C}^{\text {high }}$ cells [37]. While CLP significantly increased the percentage of splenic CD11 $\mathrm{b}^{+} \mathrm{Ly} 6 \mathrm{G}^{+} \mathrm{Ly} 6 \mathrm{C}^{\text {low }}$ cells of granulocytic lineage in WT mice, septic $\mathrm{ST}_{2}^{-/-}$mice exhibited lower presence of $\mathrm{CD} 11 \mathrm{~b}^{+} \mathrm{Ly} 6 \mathrm{G}^{+} \mathrm{Ly} 6 \mathrm{C}^{\text {low }}$ cells (Fig. 2c and e). Regarding the capabilities of MDSCs to enhance innate immune response during early sepsis, it seems that ST2 receptor signaling is important for early generation of these cells thus contributing to the development of protective immune response in sepsis.

It is well established that the early triggering of innate immune response followed by massive release of mediators of inflammation plays a critical role in sepsis pathogenesis [38]. NK cells are the integral part of innate immunity to various types of microorganisms, including viruses, bacteria, fungi or protozoa. Apart from their direct cytotoxicity, NK cells are critically involved in reciprocal interactions with other innate immune cells either directly or by cytokine secretion [39]. NK cells are main early source of IFN- $\gamma$ in response to bacterial lipopolysaccharide thus indicating their pivotal role in early development of antimicrobial immunity and efficient bacterial clearance [40, 41]. Herein, sepsis was accompanied with significantly decreased number of splenic NK cells, followed by reduced expression of inflammatory IFN- $\gamma$ and IL-17 (Fig. 3a, b and c). However, ST2 deficiency correlated with lower expression of IFN- $\gamma$ and IL-17 among splenic NK cells following CLP (Fig. 3b, c and $\mathrm{d}$ ). The obtained data are in accordance with evidences that IL-33/ST2 signaling enhances IFN- $\gamma$ production by NK cells in IL-12 dependent manner [42, 43]. Further, it is established that IL-17 is the critical cytokine responsible for the development and mobilization of neutrophils to sites of inflammation, as well as promotion of their survival [44]. NK cells are the important source of IL-17 following certain infections such as toxoplasmosis [45]. The obtained data indicate that ST2 dependent NK cells production of inflammatory IFN- $\gamma$ and IL-17 might be important for early induction of antibacterial immunity in sepsis.

As a central link between innate and adaptive immune response, CD11c positive dendritic cells are critically involved in sepsis pathogenesis. There are evidences that dendritic cells are required for the survival of mice following CLP [46, 47]. In accordance with such findings, the total number of splenic $\mathrm{CD} 11 \mathrm{c}^{+}$, as well as CD11 $\mathrm{c}^{+} \mathrm{CD} 8 \alpha^{+}$dendritic cells was observed in septic mice of both genotypes (Fig. 4a and b). It appears that lower presence of $\mathrm{CD} 11 \mathrm{c}^{+}$dendritic cells is associated with worsen outcome in septic ST2 ${ }^{-1-}$ mice (Fig. 4a). Further, ST2 deficiency is strongly associated with decreased percentage of inflammatory $\mathrm{CD} 11 \mathrm{c}^{+} \mathrm{CD} 8 \alpha^{+}$cells as well as IL-12 expressing $\mathrm{CD} 11 \mathrm{c}^{+}$dendritic cells during sepsis (Fig. 4b and c). Inflammatory $\mathrm{CD} 11 \mathrm{c}^{+} \mathrm{CD} 8 \alpha^{+}$ dendritic cells are main producers of Th1 polarizing IL-12 and IFN- $\gamma[48,49]$. CD11 $\mathrm{c}^{+} \mathrm{CD} 8 \alpha^{+}$cells exhibit mature dendritic cells phenotype and infiltrate cervical lymph nodes and lungs during early respiratory infection with Bordetella pertussis [50]. Moreover, early depletion of $\mathrm{CD} 8 \alpha^{+}$cells during infection is strongly associated with reduced bacterial clearance [50]. Given the fact that IL-33 activates dendritic cells during antigen presentation and promotes their recruitment [51], our data implicate the crucial role of ST2 receptor signaling in dendritic cells maturation and subsequent development of protective immune response in sepsis. Additionally, there are evidences that reciprocal interactions through direct contact or soluble mediators results in activation and cytokine production by both NK and dendritic cells $[52,53]$. Herein, ST2 deficiency is accompanied with decreased presence of inflammatory dendritic cells as well as IFN- $\gamma$ and IL-17 producing NK cells (Figs. 3 and 4).

Early apoptosis of lymphocytes, but also the other immune cells including macrophages and dendritic cells, is one of the central events that contributed to immune dysregulation during sepsis $[54,55]$. Herein, significant increase in immune cells apoptosis was noticed in septic mice as evaluated by higher presence of active caspase- 3 positive nuclei as well as early apoptotic Annexin $\mathrm{V}^{+} \mathrm{PI}^{-}$ cells (Fig. 5a and b). Recently, IL-33 was recognized as 
an important protector of cell survival [56-58]. In addition, it has been reported that exogenous IL-33 exhibits immunoprotective role in polymicrobial sepsis in mice by preventing early loss of $\mathrm{T}$ and $\mathrm{B}$ lymphocytes [59]. Our data show enhanced immune cells apoptosis in spleen of septic ST2 ${ }^{-1-}$ mice compared to WT mice (Fig. 5a, b and c). Accordingly, there was a trend toward increase in early apoptosis of B cells and macrophages in septic ST2 ${ }^{-1-}$ mice in comparison with WT mice, but it did not reach statistical significance $12 \mathrm{~h}$ after CLP (Fig. $5 \mathrm{f}$ and g). Interestingly, the lack of ST2 is significantly associated with CLP-induced early apoptosis of CD11 $\mathrm{c}^{+}$ cells, indicating the loss of dendritic cells (Fig. 5d and e). The early loss of dendritic cells from secondary lymphoid organs during polymicrobial sepsis strongly predicts fatal outcome in both mice and humans [60-62]. Although CD11c is a typical dendritic cell marker, it is also possible that significant number of other cells, such as recently described $\mathrm{CD} 11 \mathrm{c}^{+} \mathrm{T}$-bet ${ }^{+} \mathrm{B}$ cells, might contribute to high percentage of early apoptotic CD11 $\mathrm{c}^{+}$cells [63]. These cells are also found to be prone to cell death. However, these data implicate the significant role of ST2 receptor signaling in preventing early dendritic cells apoptosis, thus contributing to effective inflammatory response in sepsis.

\section{Conclusion}

Taken together, the obtained data reveal that ST2 receptor signaling contributes to early development of antimicrobial immunity during sepsis. It appears that in addition to affecting influx of granulocytes, lack of ST2 profoundly alters other components of inflammatory response including myeloid precursor cells, NK and dendritic cells.

\section{Abbreviations \\ CD: Cluster of differentiation; CLP: Cecal ligation and puncture; FBS: Fetal

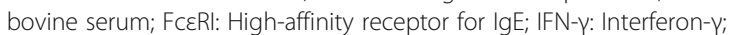 IL: Interleukin; MDSCs: Myeloid-derived suppressor cells; NK: Natural killer; PBS: Phosphate buffered saline; PI: Propidium iodide; Th: T helper; WT: Wild type \\ Funding \\ This work was supported by Ministry of Education, Science and Technological Development, Belgrade, Serbia (ON 175069, ON 175071 and ON 175103) and Faculty of Medical Sciences, University of Kragujevac (08-15 and 06-15).}

\section{Availability of data and materials}

The datasets used and/or analyzed during the current study are available from the corresponding author on reasonable request.

\section{Authors' contributions}

Conceived and designed the experiments: MLL NNA JMP. Performed the experiments: ZMB FZZ JMP IPJ GDR. Analyzed the data: MLL NNA JMP IPJ GDR. Wrote the paper: MLL JMP GDR ZMB. All authors read and approved the final manuscript.

\section{Ethics approval and consent to participate}

All animal procedures were approved by the Ethical Committee of the Faculty of Medical Sciences, University of Kragujevac, Serbia (No 01-10873/3).
Consent for publication

Not applicable.

\section{Competing interests}

The authors declare that they have no competing interests.

\section{Publisher's Note}

Springer Nature remains neutral with regard to jurisdictional claims in published maps and institutional affiliations.

\section{Author details}

'Department of Surgery, Faculty of Medical Sciences, University of Kragujevac, Kragujevac, Serbia. ${ }^{2}$ Center for Molecular Medicine and Stem Cell Research, Faculty of Medical Sciences, University of Kragujevac, Svetozara Markovica 69, Kragujevac 34000, Serbia.

Received: 6 February 2018 Accepted: 26 June 2018

Published online: 12 July 2018

\section{References}

1. Vincent JL, Opal SM, Marshall JC, Tracey KJ. Sepsis definitions: time for change. Lancet. 2013;381(9868):774-5

2. Munford RS, Pugin J. Normal responses to injury prevent systemic inflammation and can be Immunosuppressive. Am J Respir Crit Care Med. 2001:163(2):316-21.

3. Xiao W, Mindrinos MN, Seok J, Cuschieri J, Cuenca AG, Gao H, Hayden DL, Hennessy L, Moore EE, Minei JP, et al. A genomic storm in critically injured humans. J Exp Med. 2011;208(13):2581-90.

4. Stearns-Kurosawa DJ, Osuchowski MF, Valentine C, Kurosawa S, Remick DG. The pathogenesis of sepsis. Annu Rev Pathol. 2011;6:19-48.

5. Hotchkiss RS, Monneret G, Payen D. Sepsis-induced immunosuppression: from cellular dysfunctions to immunotherapy. Nat Rev Immunol. 2013; 13(12):862-74

6. Liew FY, Girard JP, Turnquist HR. Interleukin-33 in health and disease. Nat Rev Immunol. 2016;16(11):676-89.

7. Volarevic V, Mitrovic M, Milovanovic M, Zelen I, Nikolic I, Mitrovic S, Pejnovic $\mathrm{N}$, Arsenijevic N, Lukic ML. Protective role of IL-33/ST2 axis in con A-induced hepatitis. J Hepatol. 2012;56(1):26-33.

8. Jiang HR, Milovanović M, Allan D, Niedbala W, Besnard AG, Fukada SY, Alves-Filho JC, Togbe D, Goodyear CS, Linington C, Xu D, Lukic ML, Liew FY. IL-33 attenuates EAE by suppressing IL-17 and IFN- $\gamma$ production and inducing alternatively activated macrophages. Eur J Immunol. 2012;42(7): 1804-14

9. Milovanovic M, Volarevic V, Ljujic B, Radosavljevic G, Jovanovic I, Arsenijevic $\mathrm{N}$, Lukic ML. Deletion of IL-33R (ST2) abrogates resistance to EAE in BALB/C mice by enhancing polarization of APC to inflammatory phenotype. PLoS One. 2012;7(9):e45225.

10. Jovanovic I, Radosavljevic G, Mitrovic M, Juranic VL, McKenzie AN, Arsenijevic N, Jonjic S, Lukic ML. ST2 deletion enhances innate and acquired immunity to murine mammary carcinoma. Eur J Immunol. 2011;41(7):1902-12.

11. Jovanovic IP, Pejnovic NN, Radosavljevic GD, Arsenijevic NN, Lukic ML. IL-33/ ST2 axis in innate and acquired immunity to tumors. Oncoimmunology. 2012:1(2):229-31.

12. Jovanovic IP, Pejnovic NN, Radosavljevic GD, Pantic JM, Milovanovic MZ, Arsenijevic NN, Lukic ML. Interleukin-33/ST2 axis promotes breast cancer growth and metastases by facilitating intratumoral accumulation of immunosuppressive and innate lymphoid cells. Int J Cancer. 2014;134(7): 1669-82.

13. Schmitz J, Owyang A, Oldham E, Song Y, Murphy E, McClanahan TK, Zurawski G, Moshrefi M, Qin J, Li X, Gorman DM, Bazan JF, Kastelein RA. IL33, an interleukin-1-like cytokine that signals via the IL-1 receptor-related protein ST2 and induces T helper type 2-associated cytokines. Immunity. 2005;23(5):479-90.

14. Murakami-Satsutani N, Ito T, Nakanishi T, Inagaki N, Tanaka A, Vien PT, Kibata $\mathrm{K}$, Inaba M, Nomura S. IL-33 promotes the induction and maintenance of Th2 immune responses by enhancing the function of OX40 ligand. Allergol Int. 2014;63(3):443-55.

15. Miller AM. Role of IL-33 in inflammation and disease. J Inflamm (Lond). $2011 ; 8(1): 22$ 
16. Xi H, Katschke KJ Jr, Li Y, Truong T, Lee WP, Diehl L, Rangell L, Tao J, Arceo R, Eastham-Anderson J, Hackney JA, Iglesias A, Cote-Sierra J, Elstrott J, Weimer RM, van Lookeren Campagne M. IL-33 amplifies an innate immune response in the degenerating retina. J Exp Med. 2016;213(2):189-207.

17. Bessa J, Meyer CA, de Vera Mudry MC, Schlicht S, Smith SH, Iglesias A, CoteSierra J. Altered subcellular localization of IL-33 leads to non-resolving lethal inflammation. J Autoimmun. 2014;55:33-41.

18. Brunner M, Krenn C, Roth G, Moser B, Dworschak M, Jensen-Jarolim E, Spittler A, Sautner T, Bonaros N, Wolner E, Boltz-Nitulescu G, Ankersmit HJ. Increased levels of soluble ST2 protein and IgG1 production in patients with sepsis and trauma. Intensive Care Med. 2004;30(7):1468-73.

19. Hoogerwerf JJ, Tanck MW, van Zoelen MA, Wittebole $X$, Laterre PF, van der Poll T. Soluble ST2 plasma concentrations predict mortality in severe sepsis. Intensive Care Med. 2010;36(4):630-7.

20. Alves-Filho JC, Sônego F, Souto FO, Freitas A, Verri WA Jr, AuxiliadoraMartins M, Basile-Filho A, McKenzie AN, Xu D, Cunha FQ, Liew FY. Interleukin-33 attenuates sepsis by enhancing neutrophil influx to the site of infection. Nat Med. 2010;16(6):708-12.

21. Buckley JM, Liu JH, Li CH, Blankson S, Wu QD, Jiang Y, Redmond HP, Wang $J H$. Increased susceptibility of ST2-deficient mice to polymicrobial sepsis is associated with an impaired bactericidal function. J Immunol. 2011;187(8): 4293-9

22. Nascimento DC, Melo PH, Piñeros AR, Ferreira RG, Colón DF, Donate PB, Castanheira FV, Gozzi A, Czaikoski PG, Niedbala W, Borges MC, Zamboni DS, Liew FY, Cunha FQ, Alves-Filho JC. IL-33 contributes to sepsis-induced longterm immunosuppression by expanding the regulatory $T$ cell population. Nat Commun. 2017;8:14919.

23. Toscano MG, Ganea D, Gamero AM. Cecal ligation puncture procedure. J Vis Exp. 2011;51:2860.

24. Alves-Filho JC, Spiller F, Cunha FQ. Neutrophil paralysis in sepsis. Shock. 2010;34(Suppl 1):15-21.

25. Kovach MA, Standiford TJ. The function of neutrophils in sepsis. Curr Opin Infect Dis. 2012;25(3):321-7.

26. Cummings CJ, Martin TR, Frevert CW, Quan JM, Wong VA, Mongovin SM, Hagen TR, Steinberg KP, Goodman RB. Expression and function of the chemokine receptors CXCR1 and CXCR2 in sepsis. J Immunol. 1999;162(4): 2341-6.

27. Urb M, Sheppard DC. The role of mast cells in the Defence against pathogens. PLoS Pathog. 2012;8(4):e1002619.

28. Echtenacher B, Männel DN, Hültner L. Critical protective role of mast cells in a model of acute septic peritonitis. Nature. 1996;381(6577):75-7.

29. Merino CA, Martínez FT, Cardemil F, Rodríguez JR. Absolute eosinophils count as a marker of mortality in patients with severe sepsis and septic shock in an intensive care unit. J Crit Care. 2012;27(4):394-9.

30. Enoksson M, Möller-Westerberg C, Wicher G, Fallon PG, Forsberg-Nilsson K, Lunderius-Andersson C, Nilsson G. Intraperitoneal influx of neutrophils in response to IL-33 is mast cell-dependent. Blood. 2013;121(3):530-6.

31. Stolarski B, Kurowska-Stolarska M, Kewin P, Xu D, Liew FY. IL-33 exacerbates eosinophil-mediated airway inflammation. J Immunol. 2010;185(6):3472-80.

32. Gabrilovich DI, Nagaraj S. Myeloid-derived suppressor cells as regulators of the immune system. Nat Rev Immunol. 2009;9(3):162-74.

33. Ostrand-Rosenberg S, Sinha P. Myeloid-derived suppressor cells: linking inflammation and cancer. J Immunol. 2009;182(8):4499-506.

34. Cuenca AG, Delano MJ, Kelly-Scumpia KM, Moreno C, Scumpia PO, Laface DM, Heyworth PG, Efron PA, Moldawer LL. A paradoxical role for myeloid-derived suppressor cells in sepsis and trauma. Mol Med. 2011;17(3-4):281-92.

35. Delano MJ, Scumpia PO, Weinstein JS, Coco D, Nagaraj S, Kelly-Scumpia KM, O'Malley KA, Wynn JL, Antonenko S, Al-Quran SZ, Swan R, Chung CS, Atkinson MA, Ramphal R, Gabrilovich DI, Reeves WH, Ayala A, Phillips J, Laface D, Heyworth PG, Clare-Salzler M, Moldawer LL. MyD88-dependen expansion of an immature GR-1(+)CD11b(+) population induces T cell suppression and Th2 polarization in sepsis. J Exp Med. 2007;204(6):1463-74.

36. Brudecki L, Ferguson DA, McCall CE, El Gazzar M. Myeloid-derived suppressor cells evolve during Sepsis and can enhance or attenuate the systemic inflammatory response. Infect Immun. 2012;80(6):2026-34.

37. Youn II, Nagaraj S, Collazo M, Gabrilovich DI. Subsets of myeloid-derived suppressor cells in tumor-bearing mice. J Immunol. 2008;181(8):5791-802.

38. Wiersinga WJ, Leopold SJ, Cranendonk DR, van der Poll T. Host innate immune responses to sepsis. Virulence. 2014;5(1):36-44.

39. Vivier $\mathrm{E}$, Tomasello E, Baratin M, Walzer T, Ugolini S. Functions of natural killer cells. Nat Immunol. 2008;9(5):503-10.
40. Varma TK, Lin CY, Toliver-Kinsky TE, Sherwood ER. Endotoxin-induced gamma interferon production: contributing cell types and key regulatory factors. Clin Diagn Lab Immunol. 2002;9(3):530-43.

41. Souza-Fonseca-Guimaraes F, Cavaillon JM, Adib-Conquy M. Bench-tobedside review: natural killer cells in sepsis - guilty or not guilty? Crit Care. 2013;17(4):235.

42. Bourgeois E, Van LP, Samson M, Diem S, Barra A, Roga S, Gombert JM, Schneider E, Dy M, Gourdy P, Girard JP, Herbelin A. The pro-Th2 cytokine IL33 directly interacts with invariant NKT and NK cells to induce IFN-gamma production. Eur J Immunol. 2009;39(4):1046-55.

43. Smithgall MD, Comeau MR, Yoon BR, Kaufman D, Armitage R, Smith DE. IL33 amplifies both Th1- and Th2-type responses through its activity on human basophils, allergen-reactive Th2 cells, iNKT and NK cells. Int Immunol. 2008;20(8):1019-30

44. Kolls JK, Lindén A. Interleukin-17 family members and inflammation. Immunity. 2004;21(4):467-76.

45. Passos ST, Silver JS, O'Hara AC, Sehy D, Stumhofer JS, Hunter CA. IL-6 promotes NK cell production of IL-17 during toxoplasmosis. J Immunol. 2010;184(4):1776-83.

46. Scumpia PO, McAuliffe PF, O'Malley KA, Ungaro R, Uchida T, Matsumoto T, Remick DG, Clare-Salzler MJ, Moldawer LL, Efron PA. CD11C+ dendritic cells are required for survival in murine polymicrobial sepsis. J Immunol. 2005:175(5):3282-6.

47. Guisset O, Dilhuydy MS, Thiébaut R, Lefèvre J, Camou F, Sarrat A, Gabinski C, Moreau JF, Blanco P. Decrease in circulating dendritic cells predicts fatal outcome in septic shock. Intensive Care Med. 2007;33(1):148-52.

48. Maldonado-López R, De Smedt T, Michel P, Godfroid J, Pajak B, Heirman C, Thielemans K, Leo O, Urbain J, Moser M. CD8a+ and CD8a- subclasses of dendritic cells direct the development of distinct T helper cells in vivo. J Exp Med. 1999;189(3):587-92.

49. Ohteki T, Fukao T, Suzue K, Maki C, Ito M, Nakamura M, Koyasu S. Interleukin 12-dependent interferon gamma production by CD8a+ lymphoid dendritic cells. J Exp Med. 1999;189(12):1981-6.

50. Dunne PJ, Moran B, Cummins RC, Mills KH. CD11C+CD8alpha+ dendritic cells promote protective immunity to respiratory infection with Bordetella pertussis. J Immunol. 2009;183(1):400-10.

51. Besnard AG, Togbe D, Guillou N, Erard F, Quesniaux V, Ryffel B. IL-33activated dendritic cells are critical for allergic airway inflammation. Eur J Immunol. 2011;41(6):1675-86.

52. Ferlazzo G, Morandi B. Cross-talks between natural killer cells and distinct subsets of dendritic cells. Front Immunol. 2014;5:159.

53. Thomas R, Yang X. NK-DC crosstalk in immunity to microbial infection. J Immunol Res. 2016;2016:6374379.

54. Hotchkiss RS, Nicholson DW. Apoptosis and caspases regulate death and inflammation in sepsis. Nat. Rev. Immunol. 2006;6(11):813-22.

55. Wesche DE, Lomas-Neira JL, Perl M, Chung CS, Ayala A. Leukocyte apoptosis and its significance in sepsis and shock. J Leukoc Biol. 2005;78(2):325-37.

56. Seki K, Sanada S, Kudinova AY, Steinhauser ML, Handa V, Gannon J, Lee RT. Interleukin-33 prevents apoptosis and improves survival after experimental myocardial infarction through ST2 signaling. Circ Heart Fail. 2009;2(6):684-91.

57. Wang JX, Kaieda S, Ameri S, Fishgal N, Dwyer D, Dellinger A, Kepley CL, Gurish MF, Nigrovic PA. IL-33/ST2 axis promotes mast cell survival via BCLXL. Proc Natl Acad Sci U S A. 2014;111(28):10281-6.

58. Gao Y, Luo CL, Li LL, Ye GH, Gao C, Wang HC, Huang WW, Wang T, Wang ZF, $\mathrm{Ni} \mathrm{H}$, Chen XP, Tao LY. IL-33 provides neuroprotection through suppressing apoptotic, Autophagic and NF-kB-mediated inflammatory pathways in a rat model of recurrent neonatal seizure. Front Mol Neurosci. 2017;10:423.

59. Li S, Zhu FX, Zhao XJ, An YZ. The immunoprotective activity of interleukin33 in mouse model of cecal ligation and puncture-induced sepsis. Immunol Lett. 2016;169:1-7.

60. Efron PA, Martins A, Minnich D, Tinsley K, Ungaro R, Bahjat FR, Hotchkiss R, Clare-Salzler M, Moldawer LL. Characterization of the systemic loss of dendritic cells in murine lymph nodes during polymicrobial sepsis. J Immunol. 2004;173(5):3035-43

61. Hotchkiss RS, Tinsley KW, Swanson PE, Grayson MH, Osborne DF, Wagner $\mathrm{TH}$, Cobb JP, Coopersmith C, Karl IE. Depletion of dendritic cells, but not macrophages, in patients with sepsis. J Immunol. 2002;168(5):2493-500.

62. Tinsley KW, Grayson MH, Swanson PE, Drewry AM, Chang KC, Karl IE, Hotchkiss RS. Sepsis induces apoptosis and profound depletion of splenic interdigitating and follicular dendritic cells. J Immunol. 2003;171(2):909-14.

63. Karnell $J$, Kumar $V$, Wang J, Wang S, Voynova E, Ettinger R. Role of CD11c+ T-bet+ B cells in human health and disease. Cell Immunol. 2017;321:40-5. 